\title{
MANAGEMENT CONCEPT OF ISLAMIC HIGHER EDUCATION AND THE CHALLENGE IN GLOBAL ERA
}

\author{
Ahmad Bahrowi ${ }^{1}$ \\ ${ }^{1}$ Universitas Islam Nahdlatul Ulama Jepara, Indonesia \\ *Corresponding Address: barowi@unisnu.ac.id
}

Received: 5 October 2021| Approved: 20 December 2021| Published: 22 January 2022

\begin{abstract}
Management is a process of managing Islamic higher educaton institutions by taking into account the vison and mission and how to handle learning resources, methods and strategies as well as other matters relating to the achievement of educational goals effectively and effiecently. The purpose of this study is to solve the problems and challenges of Islamic higher education, especially at the level of management concepts of planning, organizing, and controlling or supervising. This research uses a qualitative research type with an analytical-descriptive approach, namely by analyzing related documents in accordance with the variables in the research or what is commonly called library research. Against the formulation and the goal of this research is to solve the problems and challanges of Islamic higher education especially at the concept level of Islamic education planning management concept is required; planning, organizing and controlling or supervising. Associated with madrasah concentration, it is necessary to have a clear concept of madrasah education planning, learning planning, the importance of lesson planning, improvement of learning quality, learning is designed with system approach, instructional design refers to how people learn, on individual students, on purpose, at ease of learning and involves learning variables toward the goal.
\end{abstract}

Keywords: Management Concept Curriculum; Islamic Higher Education; Global Era.

Abstrak: Manajemen dalam perguruan tinggi Islam adalah suatu proses pengelolaan perguruan tinggi Islam dengan memperhatikan visi, misi, dan cara menangani sumber belajar, metode, strategi, serta hal-hal lain yang berkaitan dengan pencapaian tujuan pendidikan secara efektif dan efisien. Tujuan dalam penelitian ini adalah memecahkan problematika dan tantangan dari pendidikan tinggi Islam khususnya di tingkat konsep manajemen perencanaan, pengorganisasian, dan pengendalian atau pengawasan. Penelitian ini menggunakan jenis penelitian kualitatif dengan pendekatan deskriptif analitis, yaitu dengan menganalisis dokumen-dokumen yang terkait sesuai dengan variabel-variabel dalam penelitian atau yang biasa disebut dengan penelitian kepustakaan. Terkait dengan konsentrasi madrasah, maka perlu adanya konsep yang jelas tentang perencanaan pendidikan madrasah, perencanaan pembelajaran, pentingnya perencanaan pembelajaran, peningkatan kualitas pembelajaran, pembelajaran dirancang dengan pendekatan sistem, desain pembelajaran mengacu pada bagaimana orang belajar, pada individu sisw, pada tujuan, kemudahan belajar, dan melibatkan variabel belajar menuju tujuan.

Kata kunci: Manajemen Konsep Kurikulum; Pendidikan Tinggi Islam; Era Global 


\section{INTRODUCTION}

Islamic higher education is one standard of Islamic Education in the highest level. The existence of Islamic education in various fields of education has a very large urgency as a pillar for comprehensive Islamic education. This Islamic College has a center of excellent mission to create scholars who are beneficial to the education of the ummah.

It should be noted that Islamic Higher Education has history since the time of Prophet until the era of Islamic glory. It has characteristics of Islamic teaching values. This can be seen from the curriculum which emphasizes comprehensive and integrated Islamic based courses. The basic concept of Islamic higher education used is Al-Qur'an and Al-Hadith. In this case, God says;

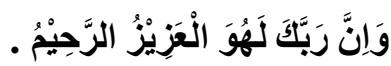

"And it is not for the believers to go forth [to battle] all at once. For there should separate from every division of them a group [remaining] to obtain understanding in the religion and warn their people when they return to them that they might be cautious".(Surah At-Tawbah 9: 122)

In deepening Islamic knowledge, surely, is required a facility (wasilah). And the facility of Islamic education in this case, of course, is not only Islamic boarding school but also Islamic Schools such as Ibtida'iyah Islamic school, Tsanawiyah Islamic School, and Aliyah Islamic School. The basic concept of higher school education development is not only taken from Al Qur'an as mentioned above, as the Word of the Prophet Muhammad SAW;

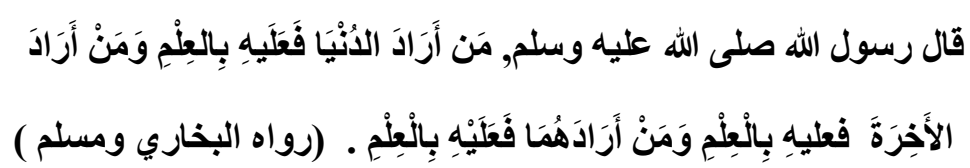

"Rasulullah SAW said, Whoever wants good in the world then with knowledge. Whoever wants good in the hereafter with knowledge. Whoever wants the good of both then with knowledge "(Narrated by Bukhari and Muslim).

From Al-Qur'an's verse and Al-Hadith mentioned above, it can be captured that Islamic higher education must be in a good management. Definition of good here means it is managed sincerely and full of resignation, because good deeds are raised to be accepted and given the reward by God. Therefore, according to technological development and the work world, Islamic higher education must deal with various challenges, However, it should be understood that in accoradance with technological developments and the world of work, especially challenges regarding global life (Drake, 2013). 
The global era is a global era or time period. It is the process of globalizing. Thus, globalization era means the age in which a global process take place. This worldwide process has occurred since the 1980s in various fields or aspects of human life, for example in the fields of politics, social, economic, religious, and especially globalization in the field of technology. The global process concretely can be understood as a development of human culture. This development has reached an extraordinary level, in which humans are moving towards the realization of a human society that covers the entire world, one global society (Baskara, 2013).

This era of transition from traditional to modern is also known as the disruptive era. The disruptive era is an era that shows very fast changes in all social fabrics of society towards digital technology. According to Nasution, the disruptive era is a phenomenon of global change that humanity must be ready to face and make life in harmony with very fast changes (Afina Mauliya $\&$ Suci Wulandari, 2021).

After the transportation and communication technology was created, there is no distance between one human to another, one ethnic group to another, one nation to another, one culture and one religion to the other. According to Haaq and Keen, information technology is a set of tools that assist work in completing tasks related to information processing, while according to Lucas information technology is "all forms of technology applied to process and transmit information in electronic form" (Lubis, 2018). The development of transportation and communication technology makes it seems as if there is no distance between cities, between islands, between countries, and between continents. In this day and age, humans easily communicate with each other in all corners of the world by using sophisticated satellites. In other words, the development of transportation and communication technology has made the world seem increasingly narrow, space and time have become more relative, and the borders of the country seem to be so easy to break through. This condition of globalization certainly not only affects the economic sector, but also has implications for Islamic higher education institutions in the world (Musrifah, 2019). The capabilities offered by communication technology, for example, can provide convenience for the continuity of business transactions. In the field of education, advances in communication and information technology have provided very broad opportunities for the community to increase knowledge. With communication and information technology, it is possible for people to study remotely or study with the help of internet and computer networks.

In particular, the problem of Islamic education in Indonesia also faces various problems and gaps in various aspects that are more complex, namely in the form of dichotomy issues of education, curriculum, goals, resources, and management of Islamic education. Efforts to repair it have not been 
carried out on a basic basis, so it seems improvised. Fundamental reform efforts are often hampered by various problems, ranging from funding issues to experts, so that Islamic education today looks increasingly less clear in its orientation (B, 2021).

\section{METHODS}

This research uses a qualitative research type with an analytical-descriptive approach, namely by analyzing related documents in accordance with the variables in the research or what is commonly called library research. According to Strauss and Corbin qualitative research is "research that can be used to examine people's lives, history, behavior, organizational functionalization, social movements, or kinship relationships" (Syahrum, 2012). The library research method is based on using analytical descriptive, with more emphasis on the strength of the analysis of existing sources and data by relying on existing theories and concepts to be interpreted based on writings that lead to the concepts and functions of education management (Fauzan Wakila, 2021). The data analysis carried out is inductivequalitative, namely based on specific facts which are carried out through data analysis based on the results of documentation collection or library research, which are then classified based on certain criteria so that unrelated data/variables will be reduced.

\section{RESULT AND DISCUSSION}

\section{Management of Islamic Higher Education}

In the Islamic perspective, everything must be done neatly, in an orderly manner, correctly, and regularly. The processes must be followed well. Everything that is done must not be careless, starting from the smallest business such as managing the household to the biggest business such as regulating state affairs. So, everything must be done with good management. Bush stated that education management should be centered on educational goals, he stated that "Educational management is a field of study and practic concerned with the operation of educational organization" (Usman, 2014).

Management is science or art to regulate the process of utilizing human resources and other sources effectively, Islamic and efficiently to achieve a certain goal. Management can also be interpreted as a distinctive process consisting of actions: planning, organizing, activating, and supervising carried to determine and achieve the targets set through the use of human resources and other sources (Abdullah, M.A., 2017). Stoner as quoted by T. Hani Handoko suggests that management is "the process of planning, organizing, directing, and supervising the efforts of members of the organization and the use of other organizational resources to achieve the goals of the 
organization that has been set". In the realm of Islam, management means the processes built on the Qur'an and Al-Hadith (Wahyudi \& Siti Julaiha, 2021).

Meanwhile, the management of Islamic education according to Sulistyorini states "A process of structuring or managing Islamic educational institutions that involves Muslim and non-Muslim human resources in moving them to achieve the goals of Islamic education effectively and efficiently(Wahyudi \& Siti Julaiha, 2021). In Arabic the term management is defined as an-nizam or at-tanzim, which means a place to store everything and the placement of everything in its place (SYABAN, 2019).

Islamic management according to Abu Sin (Saefullah, 2012), formulate four requirements that must be in it, as follows:

a. The foundation of Islamic values and morals. Islamic management must be based on the universality of values, namely compassion, honesty, justice, humanity, and equality.

b. All activities carried out are a form of servitude to Allah SWT.

c. The relationship that is built between superiors and subordinates is a relationship of brotherhood, egalitarian, and balance.

d. Islamic management that is built on the basis of ethics and religious values can be a solution to moral problems due to the times.

The definition of Islamic Higher Education can be reviewed micro and macro. The definition of Islamic higher education, in micro term, is a business form carried out to transfer or channel knowledge, values, and skills based on Islamic teachings from a teacher to students in order to form a whole Muslim person. This definition is about learning process, in which teachers and students are collaborated and the materials supported with learning media used. Meanwhile, Islamic Higher Education, in macro term, is not only limited to the distribution process which includes the three domains above, but includes history, challenges, and institutions (Helmiati, 2021). So, the definition of management in Islamic higher education is the process of managing Islamic college through the process of planning, organizing, activating, and monitoring to achieve goals/targets supported by superior human resources in order to create superior Islamic college (Tolchah, Mu'ammar, 2019).

Management of Islamic Higher Education is a process of managing Islamic higher education institution with regard to vision and mission and how to deal with sources, methods, and learning strategies and other matters related to achieving educational goals effectively and efficiently. That is a process of utilizing the resources of Muslims and educational institutions, in order to achieve educational goals effectively and efficiently to reach happiness and prosperity of the world and the hereafter can be achieved (Ninsiana, Dacholfany, 2017). 


\section{Islamic Education Planning}

Educational planning is the first step in the management process that must be carried out by an Islamic Higher Education Institution because everything or good deeds without a good plan/program will certainly be destroyed. Allah SWT says Allah SWT berfirman dalam QS. Al-Tathir: 10.

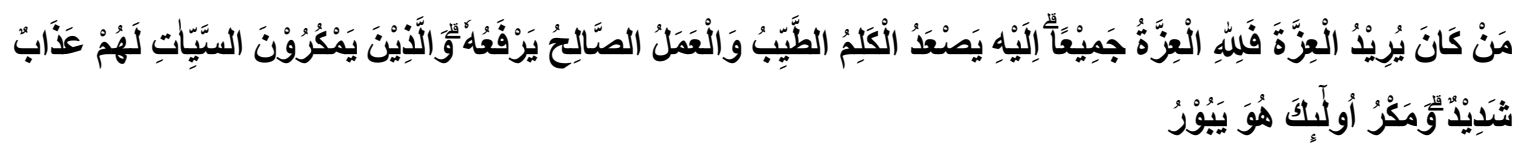

"Whoever desires honor [through power] - then to All ah belongs all honor. To im ascends good speech, and righteous work raises it. But they who plot evil deeds will have a severe punishment, and the plotting of those - it will perish (Surah Al-Fathir (35): 10).

The verse above explains that good deeds will be raised to be accepted and rewarded by Allah SWT. Therefore, a well-designed plan of Islamic higher education will automatically bring goodness and success. Good deeds here contain comprehensive, that is, starting from words, actions, and moods directed towards God that is done sincerely and not because of lust. Here Allah reminds that: Whoever wants glory, when and whenever he is, let him obey God because Allah is all the glory of all. Glory is a reflection of human knowledge and awareness of themselves and their positions. That will lead them to put themselves in the right place.

According to Quroisy Shihab, glory is different from pride, because pride is a mirror of selfignorance and position in society. Therefore, Islamic higher education planning cannot be made on the basis of pride.

\section{Organizing of Islamic Education}

Organizing is an activity in arranging and establishing working relationships among people to realize business unity in achieving goals. Organizing which has a second function in management and organization can be defined as a process to arrange organization structure in accordance with objectives and sources in accordance with their environment.

Organizing can also be meant as a process to determine, classify and regulate various activities required to achieve goals, occupy people to each activities and provide necessary things. To establish authority actively delegate to ones who carry out that activities. Regarding to organization, there are several verses in Al-Qur'an needed to be consider:

\section{a. The Need For Unity}

Related to the importance of unity in organization, Allah SWT says that: "Establish worship, pay the poor-due (zakah), and bow your heads with those who bow (in worship)." This can be seen in Surah Al-Baqarah verse 43; 


\section{Qalamuna - Jurnal Pendidikan, Sosial, dan Agama | Vol. 14 No. 1 (2022)

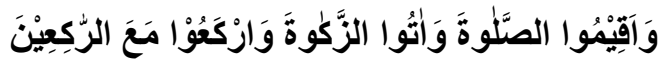

"Establish worship, pay the poor-due (zakah), and bow your heads with those who bow (in worship)."

From the verse above means prayer in congregation. Congregational prayer is a symbol of unity. In organization, unity among organs is required in which one organ and each other must synergize. Like parts of body with all functions, they move in command of brain to one goal as the target. In another verse, Allah SWT also says;

O you who have believed, take your precaution and [either] go forth in companies or go forth all together".

b. The Need for Nations

It needs to know each other among groups and nations in organization. Allah SWT says:

"O mankind, indeed We have created you from male and female and made you peoples and tribes that you may know one another. Indeed, the most noble of you in the sight of Allah is the most righteous of you. Indeed, Allah is Knowing and Acquainted (Surah Al-Hujurat: 13).

c. The Need to Unite and Follow a Straight Path

Allah SWT says in Surah Ar-Room: 31-32

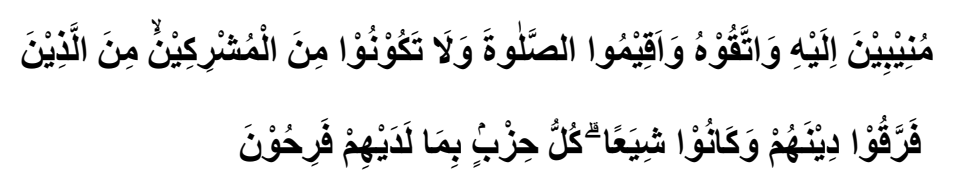

"[Adhere to it], turning in repentance to Him, and fear Him and establish prayer and do not be of those who associate others with Allah" (QS.ar-Rum: 31).

" [Or] of those who have divided their religion and become sects, every faction rejoicing in what it has."(QS. Ar-Rum: 32).

d. The Need for Mutual Help and Cooperation

Related to mutual help in the organization, Allah SWT says in Surah Al Maidah verse 2;

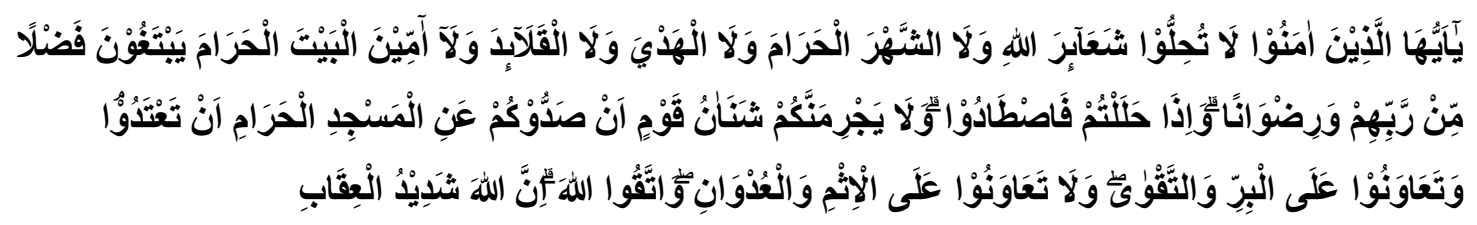


"O you who have believed, do not violate the rites of Allah or [the sanctity of] the sacred month or [neglect the marking of] the sacrificial animals and garlanding [them] or [violate the safety of] those coming to the Sacred House seeking bounty from their Lord and [His] approval. But when you come out of ihram, then [you may] hunt. And do not let the hatred of a people for having obstructed you from al-Masjid al-Haram lead you to transgress. And cooperate in righteousness and piety, but do not cooperate in sin and aggression. And fear Allah ; indeed, Allah is severe in penalty." (QS.Al-Maidah:2).

Help is an attitude of togetherness and a sense of belonging and mutual need between one another to create harmonious relationship.

\section{Activiting Islamic Education}

Allah SWT tells the Muslims to take the best path continuously, to pray, and give zakah (charity). Allah SWT menyuruh kaum muslimin supaya terus-menerus menempuh jalan sebaikbaiknya, melakukan shalat dan mengeluarkan zakat. This command is God's promise, they are help, getting victory because prayer has many lessons, strengthening faith, enhancing desires and aspirations, and enhancing mental endurance because in prayer there is prayer to Allah SWT as a statement of serious will and strengthening intertwining of hearts among believers. Allah SWT says in QS. al-Baqarah: 110, as follows



"And keep up prayer and pay the poor-rate and whatever good you send before for yourselves, you shall find it with Allah; surely Allah sees what you do." (QS. Al-Baqarah: 110).

The implementation of Islamic education must be intensified and conducted seriously as people who pray either individually or in congregation. It must be believed that whatever good is done by Muslims, it will undoubtedly get a reward from Allah SWT on the judgment day fairly. All activities Muslims conduct responsibly, with commitment/istiqamah surely Allah SWT gives good rewards even better. Allah SWT says:

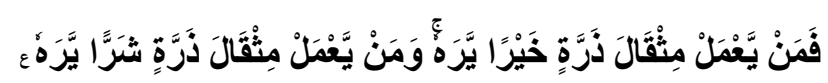

“whoever does an atom's weight of good will see it. And whoever does an atom's weight of evil will see it” (QS. Az-Zalzalah : 7-8).

The verse above is clear that if institution is regulated with good management, the effect will be good. Work hard is a must in Islam. It is mentioned in Hadith of Rasulullah. It says: "Work for yourself as if you will live forever, and pray for your hereafter as if you will die tomorrow". 


\section{Supervision of Islamic Education}

Allah SWT assigned several angels to always follow humans both in front and behind them. They guide humans by Allah commands. There are angels who guard humans at night, and there are those do guard in the daytime, and also there are angels who record all good and bad humans' deed. Two angels record humans' deed. The right hand angel records all the good deeds and the left hand angel records all bad deeds. Allah SWT says: "And indeed, [appointed] over you are keepers, (10). “ Noble and recording;(11). "They know whatever you do.(12).(QS. Al-Infitar: 10-12).

From the verses above, it can be captured that supervision as an element in management is a necessity. Without reliable supervision, of course, the institution can be judged to be poorly managed. A well-supervised institution of Islamic higher education will certainly become a highly reputed, safe, and peaceful Islamic higher education institution.

\section{Islamic Higher Education Curriculum}

Management of Islamic education and curriculum is one of the important fields, because the Islamic education curriculum is one element of Islamic education that functions to direct all forms of Islamic education activities in order to achieve the goals of Islamic education (Ilyasin, 2012). Therefore, without a curriculum an Islamic education will lose its footing in moving which causes it to lose the direction and purpose of the education. On the other hand, this is due to the fact that all aspects of the activities of the substance of Islamic education management will essentially lead to the achievement of this curriculum field management.

Islam education curriculum is designed in a format of Islamic education with a purpose to create Muslims generation who are reliable and characterized. The curriculum is essentially the planning of materials and experiences of students and products that are provided as a reference in planning, implementing, and evaluating learning. Substantively the format of Islamic education curriculum is a pattern that plans goals, materials, methods, contents and evaluations in achieving the goals of Islamic education, to make people devoted to Allah as stated in the Qur'an and al-Hadith.

Islam, in fact, has established a perfect method which involves various aspects of humans' life. If they apply that method in a good way, they become a perfect Muslims in society and they are able to realize the purpose of Islamic education as they expect to be. Discipline of Islamic education always instructs to prepare sholeh children. It is not only about preparing sholeh children, but Islam also has outlined several aspects of Muslims' personality. They are people who have sincerity as Muslims personally in the world. Allah SWT says; "And the servants of the Most Merciful are those 
who walk upon the earth easily, and when the ignorant address them [harshly], they say [words of] peace" (QS. Al-Furqan: 63).

Islam governs the entire Muslims life, determining when a Muslim must sleep, wake up, pray, work, and invest. Shortly, Islam governs all human beings' activities start from wake up in the morning until sleep at night. Comprehesively, the curriculum of Islamic higher education is in the Qur'an and Al-Hadith. These two sources are rational in fostering education system. The more it is known as truth of faith, the more truth it can be accepted by humans' ratio and history proves. The ideal format of alternative Islamic higher education can support integration with the format of Pesantren (Islamic boarding school) education. In Islamic boarding school (pesantren), there are classic books taught, they are: Format kurikulum alternatif pendidikan tinggi Islam yang ideal dapat diusulkan adanya integrasi dengan format pendidikan pesantren. Dalam pesantren terdapat kitabkitab klasik yang diajarkan, antara lain: Nahwu-Shara, Fiqh, Ushul fiqh, Hadith, Tafsir, Tawheed, Sufism, Arabic, Aqaid, Tarih. Courses integrated with pesantren's lesson are expected to solve the problems of nation character. At least three alternatives used are healthy and characteristic curriculum and an integrated curriculum guided by both al-Qur'an dan al-Hadits in purpose, method, content, and evaluation.

\section{Challenges of Islamic Higher Education in The Global Era}

The global era is a global era or time period. It is the process of globalizing. Thus, globalization era means the age in which a global process take place. This worldwide process has occurred since the 1980s in various fields or aspects of human life, for example in the fields of politics, social, economic, religious, and especially globalization in the field of technology (Baskara, 2013). The global process concretely can be understood as a development of human culture. This development has reached an extraordinary level, in which humans are moving towards the realization of a human society that covers the entire world, one global society.

By the transportation and communication technology, there is no distance between one human to another, one ethnic group to another, one nation to another, one culture and one religion to the other. The development of transportation and communication technology makes it seems as if there is no distance between cities, between islands, between countries, and between continents (Pewangi, 2017). In this day and age, humans easily communicate with each other in all corners of the world by using sophisticated satellites. In other words, the development of transportation and communication technology has made the world seem increasingly narrow, space and time have become more relative, and the borders of the country seem to be so easy to break through. 
The meaning of globalization era in this time period in which globalized process occurs makes all big cities in the world like what is whispered in Jakarta or in Kuala Lumpur are also heard in New York, and vice versa. These phenomena actually want to say that transportation and communication technology can connect people all over the world, then it creates one life and one community including life history they have. Apart from technology and communication, which have become one of the important centers in global development, according to Jack Ma, founder of Alibaba Group, Global change or what is now referred to as the disruptive era, soft skill competencies must be possessed in facing this global challenge. One of the soft skill competencies that must be possessed is the ability to empathize. According to Ang and Goh, this empathy is divided into two, namely cognitive empathy and affective empathy (Afina Mauliya \& Suci Wulandari, 2021).

The challenges of Islamic higher education today are far different from the challenges of Islamic education as found in classical and middle-age. Challenges of Islamic education internally and externally in classical and middle age are hard enough. But psychologically and ideologically those are easier to overcome (Adnan, 2019). Besides the battle of major ideologies as a challenge of Islamic higher education Challenges face today as mentioned above, another challenge is also faced like a big storm. According to Daniel Bell, in the global era, the world condition today is signed by five tendencies, they are:

a. The tendency to economic integratin

b. The tendency to political tragmentation

c. The tendency to use advanced technology, especially Communication and Information Technology (CIT) such as computers

d. The tendency to interdependency

e. The tendency to new colonization in culture which change mindset of society toward education

In addition, several main problems that describe the atmosphere of the Islamic education world are generally more than three, namely:

a. Dichotomy. It is a conflict between religious and cultural dualism. In education context, it separates two groups of courses, they are religion course and general courses to be delivered to students.

b. To general knowledge, which is too dominant

c. Lack of spirit inquiry to hold research.

Another problem that is often faced by Islamic universities is the decreasing number of studies and scientific quality among Islamic universities. Even if there is, the stretch is only political (there 
are interests) rather than academics. These two problems are caused by the weakness of Islamic college students in understanding Islamic sciences in a tahqiq manner. This is due to the lack of commitment from these Islamic universities in recruiting prospective students and recruiting prospective lecturers. As a result, prospective students who are accepted do not have the basic Islamic material expected (Dalmeri \& Supadi, 2019).

\section{CONCLUSION}

Islamic Higher Education Management is a process of managing Islamic higher education institutions regard to the application of vision and mission as well as the ways to deal with sources, methods, and learning strategies that involve the process of planning, organizing, activating, directing and supervising Islam in order to achieve the expected goals in accordance with the concept the Qur'an and al-Hadith.

In addition, to face global challenges, it is also necessary to form/compile an Islamic higher education curriculum that is guided by Islamic values. The curriculum is essentially the planning of materials and experiences of students and products that are provided as a reference in planning, implementing, and evaluating learning. Substantively the format of Islamic education curriculum is a pattern that plans goals, materials, methods, contents and evaluations in achieving the goals of Islamic education, to make people devoted to Allah as stated in the Qur'an and al-Hadith.

The challenge of Islamic higher education in this globalization era is not only to face the new ideologies but also to face several tendencies which are like the heavy storm, they are: 1) Tendency to economy, 2) tendency to politic fragmentation, 3) Tendency to sophisticated technology, 4) Tendency to interdependency, and 5) Tendency to new colonization in culture to foster people's mindset toward education.

\section{REFERENCES}

Adnan, M. (2019). Urgensi Penerapan Manajemen Pendidikan Islam Di Era Global. Munaqasyah: Jurnal Ilmu Pendidikan Dan Pembelajaran, 1(1).

Abdullah, M. A. (2017). Islamic Studies In Higher Education In Indonesia: Challenges, Impact And Prospects For The World Community. Al-Jami'ah: Journal of Islamic Studies, 55(2), 391-426.

Afina Mauliya, \& Suci Wulandari. (2021). Empathy Dan Design Thinking Dalam Inovasi Manajemen Pendidikan Islam Di Era Disruptif. Paedagogia: Jurnal Pendidikan, 10(1). https://doi.org/10.24239/pdg.vol10.iss1.139 
B, B. (2021). Manajemen Pendidikan Islam. Management of Education: Jurnal Manajemen Pendidikan Islam, 7(2). https://doi.org/10.18592/moe.v7i2.5429

Baskara, I. G. K. (2013). Perkembangan Pemikiran Manajemen Dari Gerakan Pemikiran Scientific Management Hingga Era Modern. Jurnal Manajemen, Strategi Bisnis Dan Keiwrausahaan. https://doi.org/https://doi.org/10.24843/MATRIK:JMBK

Dalmeri, \& Supadi. (2019). Membangun Manajemen Mutu Dengan Prinsip Six Sigma Pada Lembaga Pendidikan Islam Di Era Global. In Al-Fikri: Jurnal Studi dan Penelitian Pendidikan Islam (Vol. 2, Issue 1).

Drake, S. M. (2013). Menciptakan Kurikulum Terintegrasi yang Berbasis Standar Seri Kurikulum Inti. Indeks.

Fauzan Wakila, Y. (2021). Konsep dan Fungsi Manajemen Pendidikan. Equivalent : Jurnal Ilmiah Sosial Teknologi, 3(1). https://doi.org/10.46799/jequi.v3i1.33

Helmiati, H. (2021). Faktor-faktor Lokal dan Global Dalam Implementasi Manajemen Pendidikan Islam. NUR EL-ISLAM: Jurnal Pendidikan Dan Sosial Keagamaan, 8(1). https://doi.org/10.51311/nuris.v8i1.263

Ilyasin, M. \& N. N. (2012). Manajemen Pendidikan Islam (1st ed.). Aditya Media Publishing.

Lubis, I. \& M. S. (2018). SMART Economy Kota Tangerang Selatan (Syamruddin (ed.); 1st ed.).

Musrifah, M. (2019). Analisis Kritis Permasalahan Pendidikan Islam Indonesia di Era Global. Journal of Islamic Studies and Humanities, 3(1). https://doi.org/10.21580/jish.31.2341

Ninsiana, W., \& Dacholfany, M. I. (2017). Reorientation of Islamic Higher Education Leaders in Dealing With The Global World. Al-Ulum, 17(2).

Pewangi, M. (2017). Tantangan Pendidikan Islam Di Era Globalisasi. TARBAWI : Jurnal Pendidikan Agama Islam, 1(1). https://doi.org/10.26618/jtw.v1i1.347

Saefullah, U. (2012). Manajemen Pendidikan Islam (B. A. Saebani (ed.); 1st ed.). CV Pustaka Setia.

SYABAN, M. (2019). Konsep Dasar Manajemen Pendidikan Islam. AL-WARDAH, 12(2). https://doi.org/10.46339/al-wardah.v12i2.141

Syahrum, S. dan. (2012). Metodologi Penelitian Kualitatif; Konsep dan Aplikasi dalam Ilmu Sosial, Keagamaan dan Pendidikan (Haidir (ed.); 5th ed.).

Tolchah, M., \& Mu'ammar, M. A. (2019). Islamic Education in The Globalization Era; Challenges, Opportunities, and Contribution of Islamic Education in Indonesia. Humanities \& Social 
MANAGEMENT CONCEPT OF ISLAMIC HIGHER EDUCATION AND THE CHALLENGE IN GLOBAL ERA

Ahmad Bahrowi

Sciences Reviews, 7(4).

Usman, H. (2014). Manajemen; Teori, Praktik, dan Riset Pendidikan (4th ed.). PT Bumi Aksara.

Wahyudi \& Siti Julaiha, Y. (2021). Konsep Manajemen Pendidikan Umum Vis A. Borneo Journal of Islamic Education, I(1). 